\title{
SOUTHEAST ASIAN TIN GRANITOIDS OF CONTRASTING TECTONIC SETTING
}

\author{
Charles S. Hutchison \\ Department of Geology, University of Malaya, \\ Kuala Lumpur, Malaysia \\ (Received June 22, 1978; Revised September 29, 1978)
}

The three major tin granitoid belts are, from west to east:

a) Western: From Phuket to Tenasserim. The tin deposits are associated with highlevel Cretaceous adamellite, granite and pegmatite. The mineralization extends over a wide vertical extent.

b) Main Range: From Bangka to South Thailand. The tin deposits are associated with deep-seated large-microcline granite and adamellite of late Carboniferous and late Triassic age. The mineralization is confined to the roof zones of the batholith.

c) Eastern: From Billiton to Pahang-Trengganu. The tin-tungsten deposits are associated with adamellite to granite of Permian to mid Triassic high-level plutons. Mineralization extends over a wide vertical extent and there is an important $\mathrm{Fe}$-Sn association.

Only the Eastern Belt can be classified as Circum-Pacific type. It represents an epizonal volcano-plutonic arc characterized by plutonic rocks ranging from gabbro, through tonalite, granodiotite, adamellite to granite. Rhyolitic ignimbritic volcanic rocks are important.

The Western Belt has some of the Eastern Belt characteristics, but lacks the range of plutonic rocks, and volcanic rocks are absent. However, the Tertiary opening of the Andaman Sea requires that the Burmese-Indonesian volcanic arc formerly was adjacent to the adamellite-granite belt.

The Main Range Belt is interpreted as resulting from crustal anatexis of the leading edge of the western craton as it attempted to subduct beneath the Eastern volcano-plutonic arc following the late Triassic closure of the central marginal basin.

\section{Introduction}

The strong contrast between the Main Range and the Eastern Belt of Peninsular Malaysia has been documented by Hutchrson (1977). The contrasts were further amplified in respect of the character of the tin mineralization, and associated iron, by HutchrSON and TAYLOR (1978) and TAYLOR and HUTCHISON (1978), who also focused attention to the distinct character of the third major S.E. Asian tin belt of Phuket-Tenasserim.

A forthcoming review of the stratigraphic and tectonic evolution of the whole Southeast Asian region (Hutchison, 1979), highlights a Paleozoic marginal basin extending southwards from Laos, through Thailand and the length of Peninsular Malaysia, separating the Main Range from the Eastern Massif. A major divergence from this interpretation (Mrtcheli, 1977) proposes that the marginal basin was the main Tethys Sea and that the massifs to the west and east were formerly connected with Gondwanaland and Eurasia respectively.

A minor narrow granitoid belt within this marginal basin has been referred to as the Central Belt (Hutchrson, 1977). It has no known tin association. 


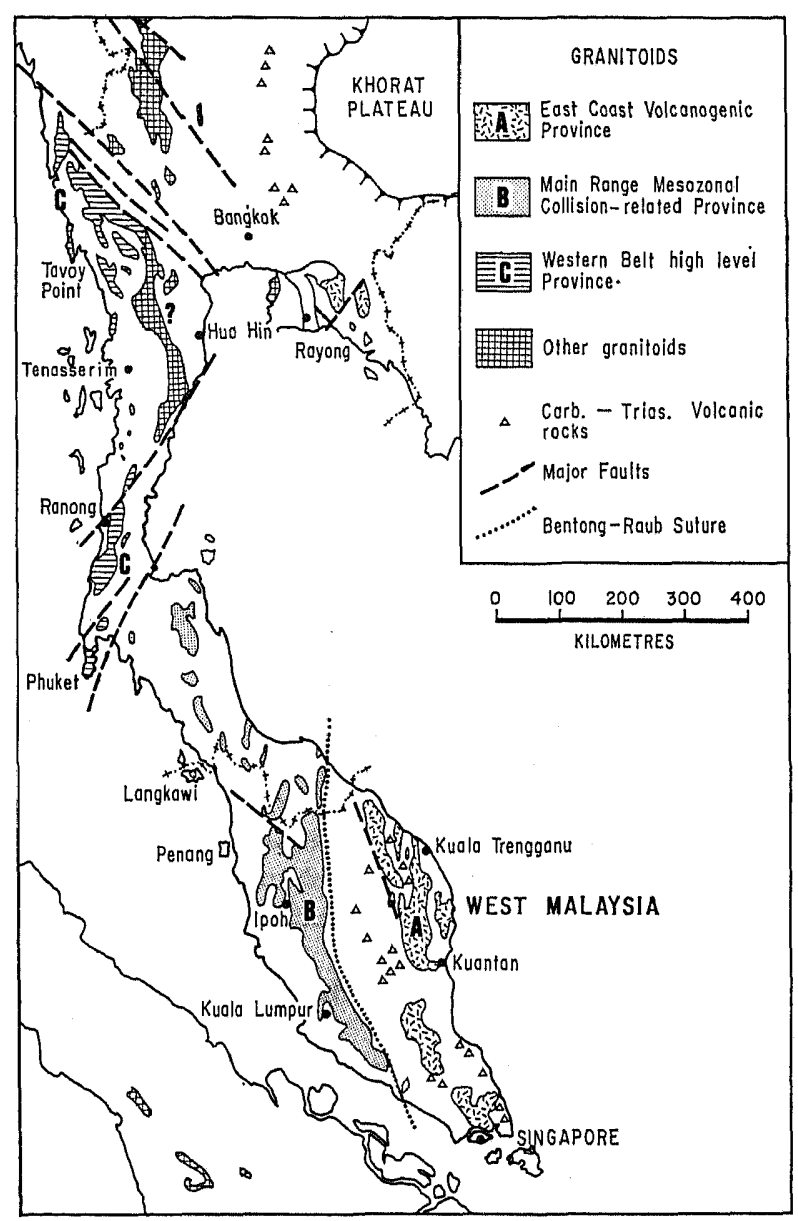

Fig. 1. The three major tin granitoid belts of Southeast Asia, after Hutchron and TAYLOR (1978). The central marginal basin separates the Main Range from the Eastern Massif and itself contains a narrow tin-barren granitoid belt which is not shown.

This paper attempts a possible tectonic evolution for the region based on the petrological characteristics of the three main tin belt granitoids. It is a revision of that of HuTCHISON (1973a) in the light of new data.

\section{The Tin Granitoid Belts}

The three major belts are shown on Fig. 1. The northern part of the Eastern Belt (A) is fault bounded on the west, but the southern part in Singapore and south Peninsular Malaysia occupies a region of low topography and poor exposure. Its western boundary is unknown, but appears offset westwards with respect to the northern part (Fig. 1). The Eastern Massif has all the characteristics of a volcano-plutonic arc (Hutchison, 1977), 
including a wide range of plutonic rocks from gabbro to granite, and coeval acid to intermediate volcanic and pyroclastic rocks. In this respect, it is of Circum-Pacific character, with close similarity to the Andes (Prtcher, 1978).

The Main Range Belt (Fig. 1, B) is of highly differentiated granite characterised by large megacrysts of maximum microcline. Finer grained varieties also occur locally. Its eastern border is represented by a narrow zone of eastwards dipping crumpled melangelike argillite containing discontinuous blocks of serpentinite, overlain locally by redbeds. This tectonic line has been referred to as the Bentong-Raub Suture (Hutchison, 1975), and from recent drilling south of Malacca (KHoo, 1978), it is now known to run out into the Straits of Malacca, and not to continue southwards to Singapore as formerly believed.

Southwards extension of these two belts is badly known, but in Indonesia the tin deposit characteristics indicate that Billiton belongs to the Eastern Massif, and Bangka to the Main Range Massif (Hutchison and TAyLOR, 1978).

Northwards extension is also badly known. Extension through the Gulf of Thailand can be inferred by important N-S trending horst and graben structures (WoLLANDs and Haw, 1976).

The Western Belt (Fig. 1, C) is apparently strongly fault-bounded, and extends northwards from Phuket into Burma. The eastwards extent of this belt is not yet defined.

Very little is known about the other tin granites shown in Fig. 1. They occur in West Central Sumatra and North Thailand.

The central marginal basin of Peninsular Malaysia, which includes the minor Central tin-barren granitoid belt, probably continues northwards through Thailand, as documented by a similar Carboniferous to Triassic succession, including contemporaneous volcanic activity (Hutchison, 1979). However, instead of the eastern margin being formed by the Eastern massif, it is formed by the Mesozoic continental basin of the Khorat Plateau. The western margin is similarly delimited by an ophiolite belt through Lampang and Houei Sai (Hutchison, 1975), similar to the Bentong-Raub Line of Peninsular Malaysia.

\subsection{Eastern Tin Belt}

The properties of the Eastern Belt are summarized in Table 1, after Hutchison and TAYLOR (1978). Radiometric data are from Bignell and SNELling (1977). A general description of the granitoids was given by Rajart et al. (1977). As stressed by Hutchison (1977), the concordance of the $\mathrm{Rb}: \mathrm{Sr}$ and the $\mathrm{K}$ : Ar dates amplifies the tectonic stability of this massif. Mineralized quartz hydrothermal veins extend far into the thermally metamorphosed country rocks.

\subsection{Main Range Tin Belt}

The properties of the Main Range Massif are summarized in Table 1. As stressed by Hurchison (1977) the strongly discordant $\mathrm{Rb}$ : $\mathrm{Sr}$ and $\mathrm{K}$ : Ar dates have been taken to mean strong post tectonic uplift. The greenschist facies country rock envelope, together with the maximum microcline of the granitoids, indicate deep seated crystallization in which the volatiles were not permitted to escape and accumulated in the roof zones of the batholiths. The lodes were therefore impounded or closely confined to the roof zones. Post crystallization uplift is indicated by shear zones and young $\mathrm{K}$ : Ar dates.

\subsection{Western Tin Belt}

The properties of the Western Belt are summarized in Table 1, from Garson et al. 
Table 1. Summary of the properties of the

\begin{tabular}{|c|c|}
\hline & Western: Phuket-Tenasserim \\
\hline Plutonic rocks & $\begin{array}{l}\text { Hornblende adamellite, biotite granite, muscovite-biotite } \\
\text { granite, pegmatite }\end{array}$ \\
\hline Volcanic rocks & $\begin{array}{l}\text { Apparently absent. The Burmese and Sumatran volcanic arc } \\
\text { may be coeval }\end{array}$ \\
\hline Granitoid texture & Equigranular to porphyritic, medium to coarse \\
\hline Colour & Pale grey or pink \\
\hline Femic minerals & Biotite, hornblende, muscovite, ilmenite \\
\hline Alkali feldspar & Orthoclase to intermediate microcline, $2 \mathrm{~V}$ not measured \\
\hline Level of emplacement & $\begin{array}{l}\text { High level granitoid plutons with well-developed thermal } \\
\text { aureoles containing cordierite and andalusite }\end{array}$ \\
\hline Age, $\mathrm{Rb}: \mathrm{Sr}$ & $\begin{array}{l}115 \pm 7 \mathrm{Ma} \\
\text { Early Cretaceous }\end{array}$ \\
\hline Age, $\mathrm{K}:$ Ar & $57 \pm 5 \mathrm{Ma}$ \\
\hline Initial $87 \mathrm{Sr} / 86 \mathrm{Sr}$ & 0.707 \\
\hline Crystallization index & 4 to 18 \\
\hline $\mathrm{K}_{2} \mathrm{O}$ weight $\%$ average & 5.6 \\
\hline $\mathrm{K}_{2} \mathrm{O} / \mathrm{Na}_{2} \mathrm{O}$ average & 2.14 \\
\hline $\mathrm{Rb} / \mathrm{Sr}$ average & 3.4 \\
\hline Tin occurrence & $\begin{array}{l}\text { Hydrothermal quartz stockworks up to } 2 \mathrm{~km} \text { long. Tin asso- } \\
\text { ciated with lithium and tantalum in pegmatites }\end{array}$ \\
\hline Tin associations & Sn-Li-Ta-W \\
\hline Post-granitoid dykes & Basaltic dykes common \\
\hline Other features & Hot springs are common. Placers abundant \\
\hline
\end{tabular}

(1975), and as shown by Hutchison (1979) the tectonic setting for the southern end at Phuket appears to continue into south Burma. This is the only belt in which major pegmatites occur and they contain significant cassiterite (TAYLOR and HuTCHISON, 1978). An unusual feature of the Phuket area is the presence of diamonds in the stanniferous placers. Their primary source is unknown. Radiometric dating of this belt is from Garson et al. (1975) and Bignell (1972). Another curious feature is that this belt appears to be strongly fault-bounded (Fig. 1) and the extent of the granites appears to coincide closely with the predominantly Carboniferous Phuket Group and analogous Mergui Formation (Hutchison, 1979). A further feature is its similarity with the Eastern Belt in that the granitoids are high level with well-developed thermal aureoles, but with a complete absence of coeval volcanic rocks and of tonalite and gabbro. As will be shown below, it is possible in a pre-Andaman Sea reconstruction, to consider a juxtaposition of the Burmese and Sumatran volcanic arc immediately to the west of this plutonic arc.

\section{Proposal for Tectonic Evolution}

From a regional stratigraphical review (Hutchison, 1979) and from the gravity survey of the Peninsula (Ryall, 1976), it can be deduced that Burma east of the Shan Scarp, 
Southeast Asia tin granitoid belts.

\begin{tabular}{|c|c|}
\hline Main Range: Kinta-Bangka & Eastern: Trengganu-Billiton \\
\hline $\begin{array}{l}\text { Large-microcline biotite granite, and } \\
\text { adamellite. Minor pegmatite. Tourmaline- } \\
\text { muscovite marginal phases }\end{array}$ & $\begin{array}{l}\text { Granite, granodiorite, tonalite, and gabbro } \\
\text { Muscovite only in marginal phases }\end{array}$ \\
\hline $\begin{array}{l}\text { No volcanic association known. Ignimbrite } \\
\text { and microgranodiorite down faulted against } \\
\text { the granite east of the Genting Highlands }\end{array}$ & $\begin{array}{l}\text { Coeval Carbo-Permian-Triassic rhyolitic to andesitic } \\
\text { lavas and pyroclastic rocks }\end{array}$ \\
\hline $\begin{array}{l}\text { Generally coarse with large microcline } \\
\text { megacrysts. Finer grained modifications in } \\
\text { margin zones }\end{array}$ & Equigranular to microporphyritic, medium to coarse \\
\hline Pale grey & Pale grey or pink \\
\hline Biotite, muscovite in greisen, ilmenite & Biotite, hornblende locally important, ilmenite \\
\hline Always Maximum microcline, $2 \mathrm{~V} 70^{\circ}$ to $90^{\circ}$ & Orthoclase to intermediate microcline, $2 \mathrm{~V} 50^{\circ}$ to $70^{\circ}$ \\
\hline $\begin{array}{l}\text { Deep-seated batholiths in greenschist facies } \\
\text { rocks. Slight increase in dynamothermal grade } \\
\text { towards contact, but no cordierite and no } \\
\text { andalusite }\end{array}$ & $\begin{array}{l}\text { Volcanogenic high level plutons with well-developed } \\
\text { thermal aureoles containing andalusite and } \\
\text { cordierite }\end{array}$ \\
\hline Maxima at $200,230,280$ & Maxima at 220,250 \\
\hline Late Carboniferous to late Triassic & Permian to Triassic \\
\hline 80 to $200 \mathrm{Ma}$ & 220 to $250 \mathrm{Ma}$ \\
\hline Carboniferous 0.711 Triassic 0.710 & Permian 0.710 Triassic 0.708 \\
\hline 0 to 14 & 0 to 25 (excluding the gabbro) \\
\hline 5.0 & 4.1 (excluding the gabbro) \\
\hline 1.7 & 1.3 (excluding the gabbro) \\
\hline 10.0 increasing westwards & 2.7 (excluding the gabbro) \\
\hline $\begin{array}{l}\text { Impounded ore bodies at granite margins } \\
\text { Tin in greisen margins and in hydrothermal } \\
\text { stockworks of limited extent }\end{array}$ & $\begin{array}{l}\text { Vertically extensive hydrothermal vein deposits in } \\
\text { overlying country rocks. Skarn and bedded lodes }\end{array}$ \\
\hline 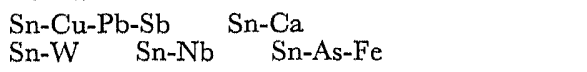 & $\mathrm{Sn}-\mathrm{Fe}$ \\
\hline Basaltic dykes generally absent & Basaltic dykes are common \\
\hline $\begin{array}{l}\text { Abundant placer deposits } \\
\text { Hot springs are common }\end{array}$ & $\begin{array}{l}\text { Placers rare, lode mining important } \\
\text { Hot springs absent }\end{array}$ \\
\hline
\end{tabular}

Peninsular and northwest Thailand as far east as Chiang Mai, and Peninsular Malaysia west of the Bentong-Raub Suture, are underlain by Precambrian continental crust. The central marginal basin occupies a positive gravity anomaly, and is therefore underlain by oceanic crust covered by a thin late Paleozoic to Mesozoic sedimentary blanket. The Eastern massif, like the Main Range, is underlain by continental crust but of lesser thickness, as shown by a slightly lesser negative gravity (RYALL, 1976). These constraints allow a reconstruction along the lines of Hutchison (1973a).

\subsection{Carboniferous}

The eastern massif is shown attached to its former craton and the central marginal basin is beginning by rifting behind the volcanic arc. This model allows for some of the Carboniferous granites of the Main Range in a back arc setting.

The craton is unknown, and has been speculated by STAUfFER (1973), after reviewing all other literature suggestions, to be North Africa. However, it now seems that the craton is to be found in Tibet, as suggested earlier by CRAWFORD (1973). The palaeomagnetic evidence is compelling, for the Malay Peninsula lay at $15^{\circ} \mathrm{N}$ during the late Palaeozoic (MoElhinny et al., 1974) and between the Permo-Triassic and the Cretaceous, it rotated $70^{\circ}$ clockwise, whilst maintaining much the same palaeolatitude. On the other 


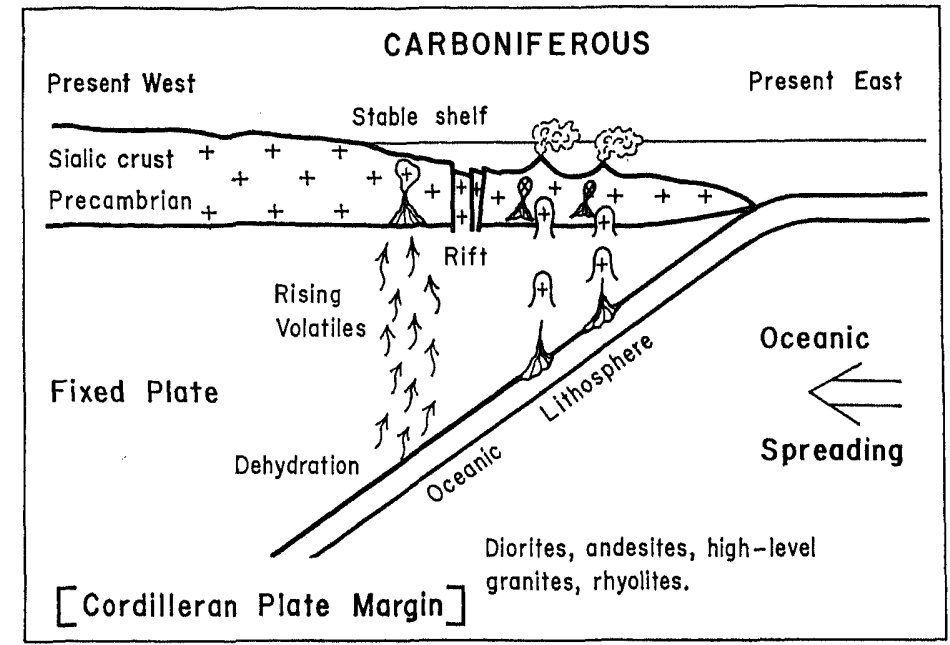

Fig. 2. Diagrammatic tectonic cross section to explain the volcano-plutonic eastern arc and the beginnings of the marginal basin. The pattern of sedimentation requires a western craton. Palaeomagnetic data indicate that the Peninsula did not maintain its present N-S orientation nor its present latitude throughout the Phanerozoic.

hand, recent palaeomagnetic data (Molnar and Chen, 1978) indicate that southern Tibet had a palaeolatitude of $8^{\circ} \mathrm{N}$ in the late Cretaceous, and has been progressively displaced northwards to its present $30^{\circ} \mathrm{N}$ position as the Asian Continent was compressed by the Indian collision. The implication is that India began colliding with mainland Asia before $38 \mathrm{Ma}$ ago. Whereas the part of Asia west of the Sagaing and Shan Scarp Fault has been displaced northwards at least $22^{\circ}$, the Malay Peninsula rebounded southeastwards by about $12^{\circ}$; a total displacement from its cratonic attachment of no less than $34^{\circ}$ of latitude.

\subsection{Permian}

Throughout the Carboniferous and the Permian, the central marginal basin continued to develop as the Eastern Massif drifted away from its ancestral craton (Fig. 3). Marine sedimentation, intercalated with rhyolitic and andesitic volcanic and pyroclastic rocks, continued into the early mid Triassic (Gobbetr, $1973 \mathrm{a}, \mathrm{b}$ ). A narrow marginal basin which is receiving active sedimentation as well as simultaneously spreading, must have a linear zone of high heat flow overlying the spreading axis. This zone can now be identified as a narrow belt of high grade metamorphic rocks extending from the Taku Schist in north Kelantan, southwards to Gunung Benom and Gunung Ledang (Hutchrson, 1973 b, p. 255).

Sedimentation onlapped onto the Eastern Massif, which was largely inundated, but the sea shoaled towards the east (Hutchison, 1979).

Marginal seas appear to have a limited life, and the rifted continental margin cannot continue oceanwards indefinitely because the mantle convection cell beneath the marginal basin is of minor importance compared with that of the main ocean. This is well illustrated by the number of extinct marginal basins to be found in Southeast Asia at the present time. 


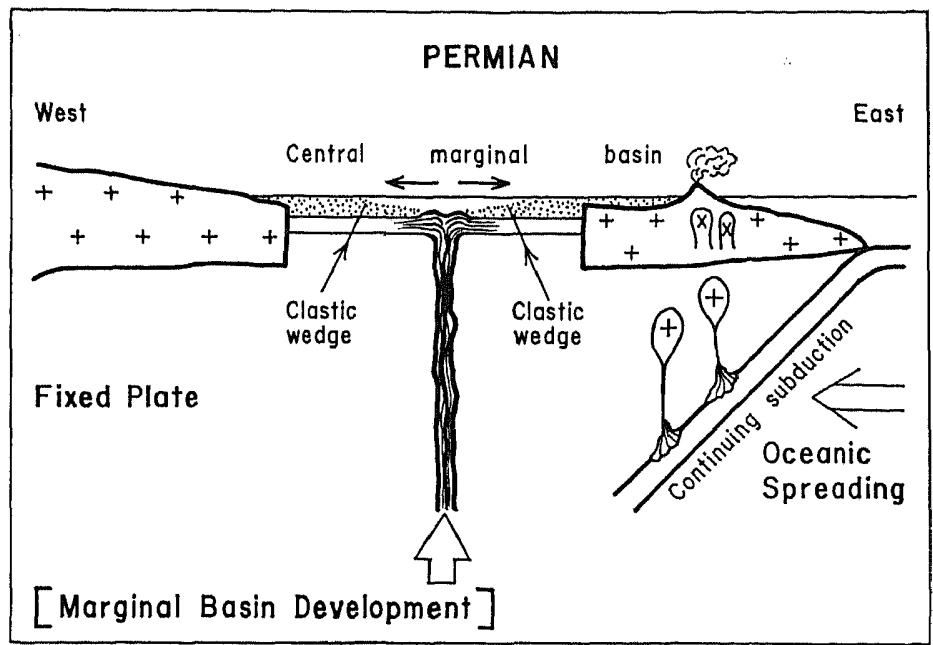

Fig. 3. The marginal basin reached its maximum development in the Permian. The Eastern Massif has a complete suite of plutonic rocks from gabbro to granite, and coeval volcanic rocks from andesite to rhyolite.

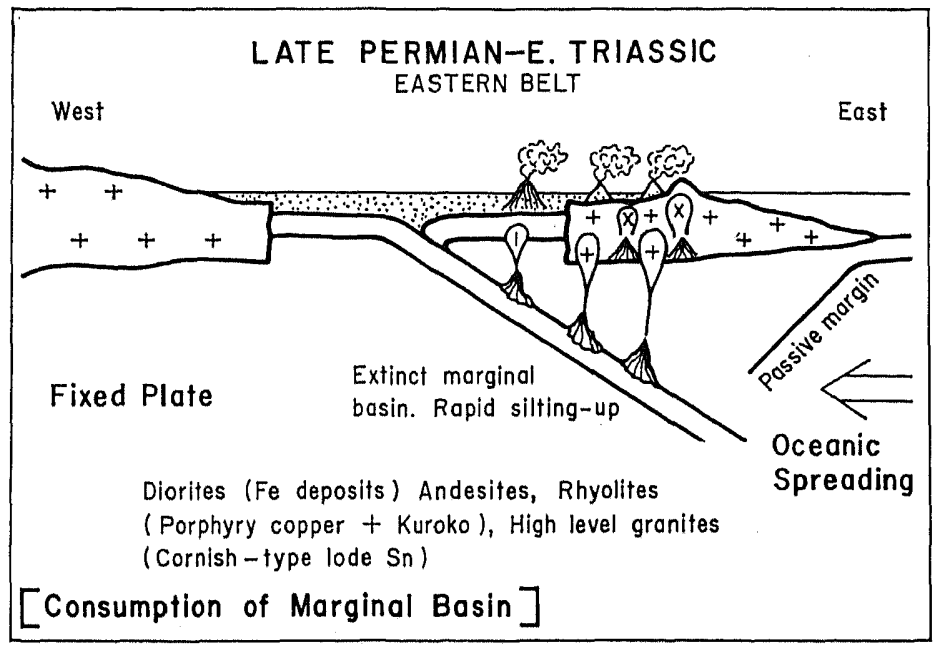

Fig. 4. Extinction of the marginal basin spreading axis, followed by flipping of the subduction polarity, leads to consumption of the marginal basin and rapid shoaling of its seas.

Subduction-related magmatism resulted in dioritic plutons within the Eastern Massif, closely associated with contact iron deposits (HuTCHISON and TAYLOR, 1978). Rising isotherms, because of the subduction-related activity, caused partial melting of the sialic basement of the Eastern Massif giving rise to granitoids. The tin and tungsten deposits associated with these granitoids is considered to have their source in the sialic basement, rifted from the main cratonic continental plate.

\subsection{Late Permian-early Triassic}

Upon extinction of spreading, it appears to be natural for the polarity of subduction 
to flip, so that the old marginal basin lithosphere is consumed (Fig. 4). This proposed mechanism is based on the present activity in the Philippines, in which the old extinct South China Sea lithosphere is being consumed along the Manila Trench, with the result that the northern Philippine islands are now approaching the mainland. But in the southern Philippines, subduction of the Pacific Plate continues along the Philippine Trench (Murphy, 1973). Thus the Philippine islands are being torn apart by a central transform fault. Such complex activity in marginal basins and island arcs can be considered to have taken place in the past. The Eastern Massif of the Malay Peninsula appears to be torn into two parts, the southern part extending farther westwards than the northern part (Fig. 1).

The model (Fig. 4) is supported by the change throughout the marginal basin from shallow marine to estuarine and continental by the late Triassic (Burton, 1973). Although the Eastern Massif was almost entirely emergent, the estuarine Jurong Formation onlapped towards the east.

The change of subduction polarity ensured continuing volcanic and plutonic activity, but any regularity of zonation has been confused by the flipping.

\subsection{Late Triassic}

As the marginal basin lithosphere continues to be consumed, the overlying sediments are folded and uplifted and marine conditions are replaced entirely by estuarine and continental. A redbed facies is now widely developed throughout the region (BuRTon, 1973; HutChrson, 1979).

Eventually the Eastern Massif, with its buffer of folded marginal basin sediments, collided with and over-rode the eastern margin of the craton (Fig. 5). I take this collision to be the main mechanism for the major late Triassic Southeast Asian orogeny.

The crustal thickenning over the region of the Main Range, coupled with under-

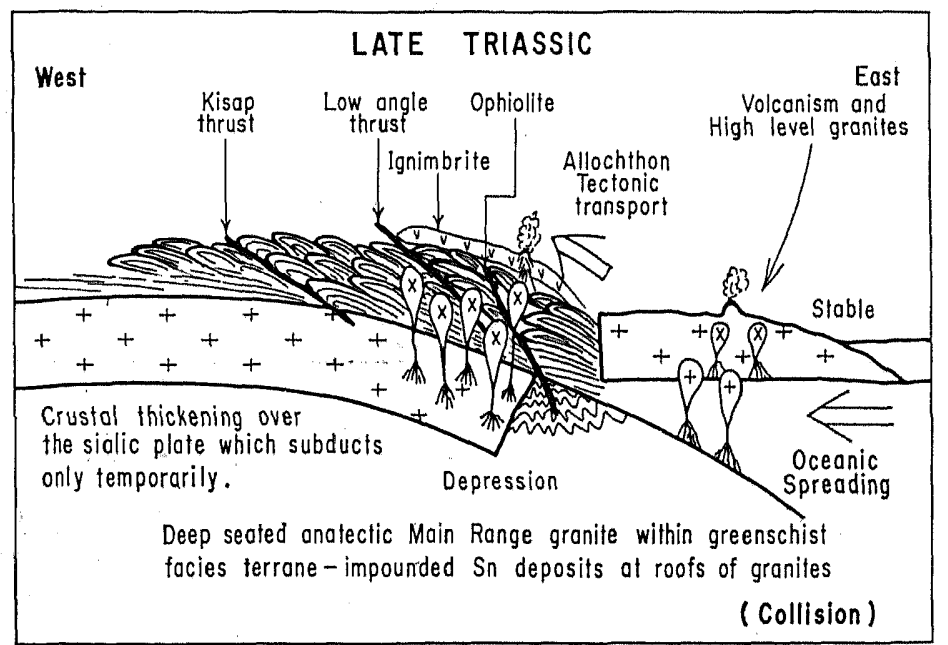

Fig. 5. Continuing contraction of the marginal basin results in collision of the Eastern island arc and its buffer of folded marginal basin sediments with the craton. Crustal thickening resulting from westwards allochthonous overthrusting of the marginal basin sediments and partial subduction of the western craton result in the anatectic deep-seated Main Range Granite. 
thrusting of the western plate, resulted in an increase of the geotherms leading to the anatectic formation of the highly differentiated Main Range Granite. Its deep-seated nature resulted from the inability of the wet anatectic magma to rise high in the folded greenschist facies pile. The main cratonic Western Massif could not continue to subduct, so that the welding of the Eastern Massif resulted in cratonization of the whole region, and active subduction thereafter jumped farther oceanwards. The whole Southeast Asian region became the large continental mass of Sundaland, characterised by extensive continental Jurassic redbeds.

The tin deposits were impounded within the roof zone of the Main Range granite because the hydrothermal tin-bearing solutions were unable to escape upwards through the unfractured greenschist facies overburden. The tin had its source in the sialic basement which was once continuous with that of the Eastern Belt. The dramatically different styles of mineralization between the two belts therefore reflects the radically different tectonic histories which caused remobilization of the tin.

\subsection{Late Mesozoic-Cenozoic}

A complete history cannot yet be written for this complex region. The only approach is to work back from the present.

The present configuration of the Andaman Sea (Fig. 6) includes E-N-E trending spreading axes connected by N-S transform faults. The analysed seismicity indicates N-S directed extension (EGUCHI et al., 1978).
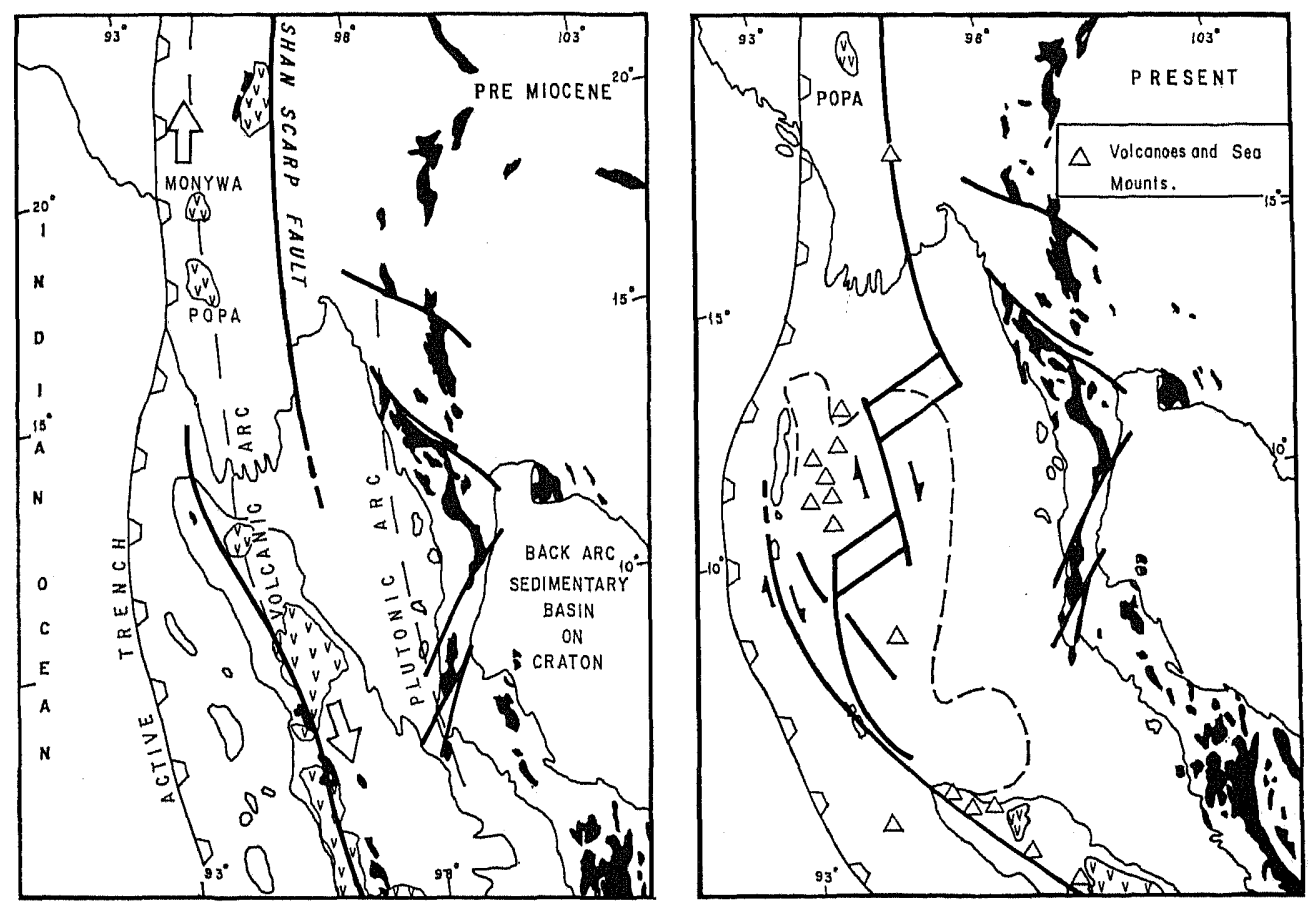

Fig. 6. The present and pre-Miocene Andaman Sea configuration. Before the marginal sea opened by N-S extension, the Burmese and Sumatran volcanic arcs must have been continuous and adjacent to the Cretaceous Phuket-Tenasserim granitic arc. 


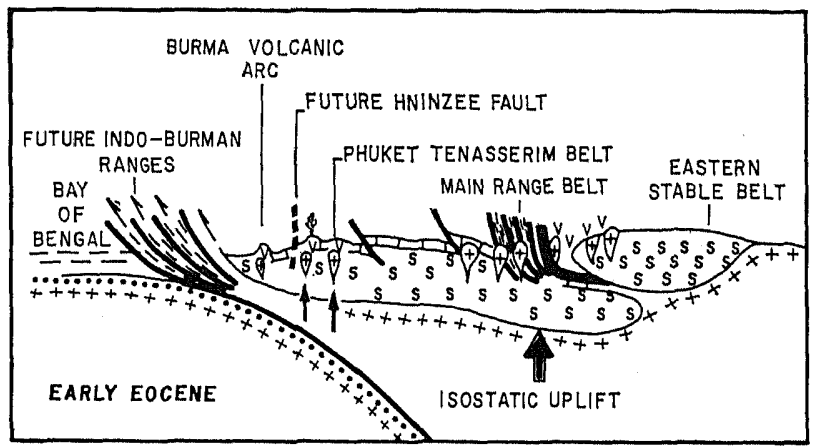

Fig. 7. Diagrammatic tectonic cross-section across Fig. 6 before the opening of the Andaman Sea (after Mitchell, 1977).

If the Andaman Sea is closed back (Fig. 6), then the Burmese and Sumatran volcanic arcs are continuous and parallel to the Cretaceous plutonic arc of Phuket-Tenasserim. The Andaman Sea has been estimated to begin its opening 10 to $20 \mathrm{Ma}$ ago (EGUCHI et al., 1978). This reconstruction allows the Burmese-Sumatran volcanic arc and the backarc Cretaceous plutonic belt to be related to Indian Ocean subduction from the present west, as shown diagrammatically on Fig. 7 (after Mrtchels, 1977). Attractive though this reconstruction is, the perfect separation of the andesitic volcanic arc from the granitic plutonic arc is enigmatic and implies that a definite answer has not yet been obtained.

To probe back beyond this is fraught with difficulty. The cratonic hinterland of the Malay Peninsula is considered to have rifted away by the Miocene, and indeed to have been away by the Cretaceous, if the granites of Phuket-Tenasserim, with ages of $115 \mathrm{Ma}$ (Table 1 ), are to be accepted. Then, what caused the separation of the Peninsula from its craton? If we seek the answer in the collision of India with Eurasia, the timing is unsuitable. The palaeomagnetic data discussed in MOLNAR and CHEN (1978) suggest a collision of India with Tibet at about $8^{\circ} \mathrm{N}$ at least before $38 \mathrm{Ma}$. But this collision age cannot be extended back to much more than about $60 \mathrm{Ma}$, when the northern part of Greater India had just reached the equator (MOLNAR and TAPPONIER, 1975).

The search for the sequence of events is frustrated by such complexities as:

1) Collision of the Indian Ocean mid-oceanic ridge with the Sumatran Trench in the mid to late Miocene (EGuchr et al., 1978).

2) The possible late Cenozoic clockwise rotation of Sumatra (NINKovich, 1976).

3) The $50^{\circ}$ anticlockwise rotation and $15^{\circ}$ of latitude southwards drift of the Malay Peninsula since the mid Cretaceous (HAILE et al., 1977).

\section{Epilogue}

Tin mineralization is closely associated with $\mathrm{K}_{2} \mathrm{O}$ - and $\mathrm{SiO}_{2}$-rich granites in three distinct belts. The epizonal granitoid belts are of Permian to Triassic age in the Eastern Massif and of Cretaceous age in the Western. Only the Eastern Massif has the complete characteristics of a volcano-plutonic arc of Circum-Pacific type. The Main Range Belt of highly differentiated maximum microcline granite, of predominantly late Triassic age, also includes some late Carboniferous granite. It has none of the characters of a volcano- 
plutonic arc and is considered to have resulted from collision of the Eastern Massif island arc with its ancestral craton as the separating marginal basin was consumed by subduction. The deep-seated anatectic granites are characterized by hydrothermal tin deposits impounded close to the granite-greenschist contact. The western Belt granites are related in some way to Indian Ocean margin tectonics, but the evolution of this region is extremely complex.

Thus, in the region of Southeast Asia, tin is genetically associated with granites of dramatically different age and tectonic setting. As argued by HuTchison and CHAKRABORTY (1978), tin deposits result from polycyclic events in the older continental crust. The three tin belts may be unified only in one respect, that they are derived from a continental basement which already contained unevenly distributed tin concentrations. Tin-bearing granite magma was remobilized from these sources at various times and by dramatically different tectonic processes which caused partial melting of the older basement.

I am grateful to the University of Malaya and the Inter-Union Commission on Geodynamics for financial support to attend the conference. Ms. Zaimah binti Ahamad Saleh typed the manuscript. Mr. Roslin bin Ismail and Mr. Ching Yu Hay drew the figures from my sketches.

\section{REFERENCES}

Branell, J.D., The geochronology of the Malayan granites, Dr. Phil. Thesis, University of Oxford, 1972. Bignell, J.D. and N.J. Snelling, Geochronology of Malayan granites. Overseas Geol. Min. Resour., 47, 1-72, 1977.

Burton, C.K., Mesozoic, in Geology of the Malay Peninsula, edited by D.J. Gobbett and C.S. Hutchison, pp. 97-141, John Wiley-Interscience, New York, 1973.

CRAwrord, A.R., A displaced Tibetan Massif as a possible source of some Malay Rocks, Geol. Mag.,109, 483$489,1973$.

Eguchr, T., S. UyedA, and T. MAKI, Seismotectonics and tectonic history of the Andaman Sea, Tectonophysics, 1978 (in press).

Garson, M.S., B. Young, A.H.G. Mrtchell, and B.A.R. Tart, 1975. The Geology of the tin belt in Peninsular Thailand around Phuket, Phangnga and Takuapa, Inst. Geol. Sci. Lond. Overseas Mem., 1, 112 pp. +map.

Gobsert, D.J., Carboniferous and Permian correlations in Southeast Asia, Geol. Soc. Malaysia Bull., 6, 131-142, 1973a.

Goвbett, D.J, Upper Palaeozoic, in Geology of the Malay Peninsula, edited by D.J. Gobbett and C.S. Hutchison, pp. 61-95, John Wiley-Interscience, New York, $1973 \mathrm{~b}$.

Harle, N.S., M.W. McElminny, and I. MoDougall, Palaeomagnetic data and radiometric ages from the Cretaceous of West Kalimantan (Borneo), and their significance in interpreting regional structure, $J$. Geol. Soc. Lond., 133, 133-144, 1977.

Hutchison, C.S., Tectonic evolution of Sundaland: A Phanerozoic Synthesis, Geol. Soc. Malaysia Bull., 6, $61-86,1973 a$.

Hurchison, C.S., Metamorphism, in Geology of the Malay Peninsula, edited by D.J. Gobbett and C.S. Hutchison, pp. 253-303, John Wiley-Interscience, New York, $1973 \mathrm{~b}$.

Hutcrison, C.S., Ophiolite in Southeast Asia, Geol. Soc. Am. Bull., 86, 797-806, 1975.

Hutchrson, C.S., Granite emplacement and tectonic subdivision of Peninsular Malaysia, Geol. Soc. Malaysia Bull., 9, 187-207, 1977.

Hutchison, C.S., Southeast Asia, in The Irdian Ocean Basin and Margins, edited by A.E.M. Nairn, F.G. Stehli, and M. Churkin, Plenum Press, New York, 1979 (in press).

Hutchison, C.S. and K.R. Chakraborty, Tin: A mantle or crustal source? (extended abstract in Commonwealth Geological Liason Office Newsletter, July 1978, 8-10), Geol. Soc. Malaysia Bull., 11, 1978 (in press).

Hutchison, C.S. and D. TAxLoR, Metallogenesis in SE Asia, J. Geol. Soc. Lond., 135, 407-428, 1978.

Kноо, K.K., Serpentinite occurrence at Telok Mas, Malacca, Geol. Soc. Malaysia Newslett., 4, 1-5, 1978.

McElfinny, M.W., N.S. HAIre, and A.R. Crawford, Palaeomagnetic evidence shows Malay Peninsula was not a part of Gondwanaland, Nature, 252, 641-645, 1974. 
Mrtcheld, A.H.G., Tectonic settings for emplacement of Southeast Asian tin granites, Geol. Soc. Malaysia Bull., 9, 123-140, 1977.

Molnar, P. and Chen Wang-Ping, Evidence of large Cainozoic crustal shortening of Asia, Nature, 273, 218$220,1978$.

Molnar, P. and P. Tapponter, Cenozoic tectonics of Asia: Effects of a continental collision, Science, 189, 419$426,1975$.

Murphy, R.W., Diversity of Island Arcs: Japan, Philippines, Northern Moluccas, Aust. Petrol. Exp. Assoc. J., 13, 19-25, 1973.

Ninkovich, D., Late Cenozoic clockwise rotation of Sumatra, Earth Planet. Sci. Lett., 29, 269-275, 1976.

PItcher, W.S., The anatomy of a batholith, J. Geol. Soc. Lond., 135, 157-182, 1978.

RaJah, S.S., F. Chand, and D.S. Singh, The granitoids and mineralization of the Eastern Belt of Peninsular Malaysia, Geol. Soc. Malaysia Bull., 9, 209-232, 1977.

Ryall, P.J., Gravity traverse of Peninsular Malaysia-Preliminary results, Geol. Soc. Malaysia, Ipoh Meet. Abstr., Dec. 1976, 1976.

Stauffer, P.H., Malaya and Southeast Asia in the pattern of continental drift, Geol. Soc. Malaysia Bull., 7, 89-138, 1973.

TAYlor, D. and C.S. Hutchison, Patterns of Mineralization in Southeast Asia, their relationship to broadscale geological features and the relevance of plate-tectonic concepts to their understanding, Proc. XI Comm. Min. and Metall. Congr. Hong Kong, Inst. Min. and Metall. Lond., Paper 68, 15 pp. 1978.

Woollands, M.A. and D. HAw, Tertiary stratigraphy and sedimentation in the Gulf of Thailand, Southeast Asia Petrol. Exp. Soc. Offshore S. E. Asia Conf., Feb. 1976, Paper 7, 1976. 